\title{
Disseminated gonorrhea with laryngeal involvement in a 25-year-old man
}

\author{
François Voruz MD, Igor Leuchter MD
}

Cite as: CMAJ 2021 May 3;193:E646. doi: 10.1503/cmaj.202183

A healthy immunocompetent 25-year-old married man presented to the emergency department with a 5-day history of severe odynophagia, fever (peak $40^{\circ} \mathrm{C}$ ), and a scattered pustular skin eruption. He denied extramarital sexual relations. The patient's physical examination was remarkable for scattered fibrinous lesions in his pharynx and larynx (Figure 1; Appendix 1 video, available at www.cmaj. ca/lookup/doi/10.1503/cmaj.202183/tab -related-content) and pustular lesions on the trunk, limbs and scrotum. He did not have urethritis.

Polymerase chain reaction of a skin pustule identified Neisseria gonorrhoeae, consistent with a diagnosis of disseminated gonococcal infection with laryngeal involvement. Investigations for HIV, syphilis, chlamydia and herpes simplex infection were negative. The patient was admitted to hospital and received intravenous fluids, nasogastric tube feeding, fentanyl and intravenous ceftriaxone, after consultation with our infectious disease team. The lesions resolved in 9 days. His spouse tested negative and was not treated for gonorrhea. We were unable to determine the source of his infection but concluded that asymptomatic gonococcal carriage was a plausible explanation.

Gonococcal infection is a sexually transmitted disease contracted during vaginal, anal or oral sex that largely affects mucosal surfaces and manifests mostly as a localized genitourinary tract infection. ${ }^{1}$ In 2017, the incidence of gonorrhea in Canada was $79.5 / 100000$, which was more than double the 2013 incidence. $^{2}$

Disseminated infection occurs through hematogenous spreading of $N$. gonorrhoeae, and usually manifests as tenosynovitis, arthritis, skin lesions and, very rarely, meningitis, endocarditis and osteomyelitis. ${ }^{3}$ Pharyngeal involvement occurs in about $3 \%$ of infections and is often asymptomatic, with oral sex being the main risk factor. ${ }^{4,5}$ The differential diagnoses include infectious and reactive arthritis, herpes simplex, HIV and syphilis infections.

Because of penicillin and fluoroquinolone resistance, thirdgeneration cephalosporins, such as ceftriaxone, are recommended, although resistant strains are emerging and becoming problematic. ${ }^{1}$ When assessing cutaneous lesions, consider sexually transmitted infections, take a thorough sexual history and examine for atypical systemic manifestations, such as pharyngolaryngitis.

\section{References}

1. Hill SA, Masters TL, Wachter J. Gonorrhea - an evolving disease of the new millennium. Microb Cell 2016;3:371-89.

2. Report on sexually transmitted infections in Canada, 2017. Gonorrhea. Ottawa: Public Health Agency of Canada; modified 2020 Jan. 27. Available: www.canada. ca/en/public-health/services/publications/diseases-conditions/report-sexually -transmitted-infections-canada-2017.html\#a5 (accessed 2020 Oct. 29).

3. Bleich AT, Sheffield JS, Wendel GD Jr., et al. Disseminated gonococcal infection in women. Obstet Gynecol 2012;119:597-602.

4. Chan PA, Robinette A, Montgomery M, et al. Extragenital infections caused by Chlamydia trachomatis and Neisseria gonorrhoeae: a review of the literature. Infect Dis Obstet Gynecol 2016;2016:5758387.

5. Balmelli C, Gunthard HF. Gonococcal tonsillar infection - a case report and literature review. Infection 2003;31:362-5.

Competing interests: None declared.

This article has been peer reviewed.

The authors have obtained patient consent.

Affiliation: Otorhinolaryngology and Head and Neck Surgery, Geneva University Hospitals, Switzerland

Content licence: This is an Open Access article distributed in accordance with the terms of the Creative Commons Attribution (CC BY-NCND 4.0) licence, which permits use, distribution and reproduction in any medium, provided that the original publication is properly cited, the use is noncommercial (i.e., research or educational use), and no modifications or adaptations are made. See: https://creativecommons.org/licenses/by-nc-nd/4.0/

Correspondence to: François Voruz, francois.voruz@hcuge.ch

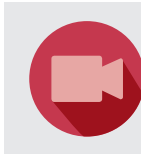

Please see the accompanying video online, "Disseminated gonorrhea: scattered fibrinous lesions in the pharynx and larynx," available at www.cmaj.ca/lookup/doi/10.1503/ cmaj.202183/tab-related-content 